\title{
A five year study of floristic succession in a restored urban wetland
}

\author{
Mengchi Ho*, Curtis J. Richardson \\ Duke University Wetland Center, Nicholas School of the Environment, Box 90333, Durham, NC 27708, USA
}

\section{A R T I C L E I N F O}

\section{Article history:}

Received 15 December 2012

Received in revised form 1 May 2013

Accepted 2 May 2013

Available online 12 June 2013

\section{Keywords:}

Plant succession

Microstegium vimineum

Intermediate disturbance hypothesis

Wetland restoration

Urban wetland

\begin{abstract}
A B S T R A C T
The Stream and Wetland Assessment Management Park (SWAMP) project created a wetland-stream complex that encompasses a wide array of micro-environments and hydrology. These diverse habitats were designed to facilitate ecosystem diversity via enhanced pathways for ecological succession during restoration. We took an empirical approach to examine floral succession under natural processes following wetland restoration of floodplain and marsh habitats. Survey plots were set up in four forest gaps in palustrine wetlands, each containing a Low Marsh and a High Marsh. During five years of recovery from the soil disturbance and upland vegetation removal, wetland species richness gradually increased from 24 to 38 species in the Low Marshes, where waterlogged conditions precluded upland species invasions. Conversely, upland species richness quickly declined from 69 to 29 species over time in the High Marsh, now subjected to increase flooding. The species successional patterns suggest a slower turnover in the wet Low Marsh, but faster turnover in the moist High Marsh. Following the intermediate disturbance hypothesis, we observed that High Marsh species richness reached its maximum in the first year of the vegetation survey, whereas even after five years the plant diversity in the Low Marsh has yet to peak. The once widespread Ligustrum sinense (Chinese privet) was decimated following the SWAMP restoration. However, the exotic invasive species, Microstegium vimineum (Japanese stilt grass) dominated the floodplain except in the wettest Low Marsh sites. Given the successional patterns of increased wetland species following restoration, we recommend removal of woody invasive species such as $L$. sinense to prevent their re-establishment followed by long-term monitoring and continued removal (5-7 years) of invasive species to allow native species establishment. Our study shows that the creation of wetter floodplain habitats with increased flooding suppresses the establishment of the highly invasive M. vimineum.
\end{abstract}

(c) 2013 Elsevier B.V. All rights reserved.

\section{Introduction}

Parks and natural areas that showcase wetland habitat are rare. Most of them are found in natural preserves remote from populous cities. Much of the waterfront in major world metropolis, such as New York, Shanghai, Moscow, London, and Paris, were once dominated by wetlands. Drainage, farming, and urbanization erased these prevalent natural features. Today wetland parks in an urban setting are minuscule compared with the vast cityscape. Wetland areas that could be stewarded for ecosystem service are often converted by urban development and infrastructure to maximize their economic output (Richardson, 1994; Costanza et al., 1997).

The Stream and Wetland Assessment Management Park (SWAMP) was established in the upper reach of the Sandy Creek watershed, Durham, North Carolina, in 2005. Nested within foot paths and bike trails in Duke Forest, SWAMP is bordered by Duke University West Campus in upstream Sandy Creek, whereas the

\footnotetext{
* Corresponding author. Tel.: +1 919613 8007; fax: +1 9196138101.

E-mail addresses: mho@duke.edu (M. Ho), curtr@duke.edu (C.J. Richardson).
}

side branches are surrounded by residential housing. Since 1957 , the downstream drainage area of the SWAMP floodplain and adjacent landscape has been converted to a highly valued and intensely maintained Duke University golf course and driving range. While the golf club developed into an economic success, the upstream bottomland hardwoods received little attention and became a highly disturbed and non-functioning former wetland cutoff from the severely eroded stream traversing the area (Richardson et al., 2011). In 2005 a multi-purpose wetland park concept was formulated. It was dedicated in 2007 by the University as the Stream Wetland Assessment Management Park (SWAMP) for research and teaching as well as treating $>400$ ha of urban Durham City and Duke University stormwater runoff.

Since the inception of SWAMP, the water quality in Sandy Creek has improved with significant reductions of $\mathrm{NO}_{3}$ by $64 \%$ and $\mathrm{PO}_{4}$ by $28 \%$ in the stream flow (Richardson et al., 2011). Sandy Creek flows into New Hope Creek, which in turn feeds Jordan Lake, a reservoir that provides drinking water for the surrounding cities and townships. While the SWAMP project serves its purpose in mitigating water pollution, the environmental health of the neighboring wetland is yet to be examined. Osland et al. (2009) explored 
the potential of using native Arundinaria gigantea to outcompete the exotic shrub, Ligustrum sinense (Chinese privet). Unghire et al. (2011) studied the impact of wetland restoration on soil properties with respect to spatial variability. They reported some negative effects of nutrient losses that resulted from construction activities during restoration. Plant functional diversity resulted in increased denitrification in enriched soil in the SWAMP site (Sutton-Grier et al., 2011).

In our study, we focused on restoration of groundwater hydrologic patterns and plant community recovery following wetland restoration. We also examined the interrelation between hydrology and plant diversity in our urban setting. Just as human activity may bring about eutrophication of the water resources, urban development can be the center of exotic plant dispersal. A vegetation survey, conducted in 2004 before restoration, revealed a plant assemblage infested by exotic invasive plants among many native upland woody species in understory stratum. The pre-restoration flora, which was dominated by $L$. sinense with a $30 \%$ relative density and a $22 \%$ relative frequency, suggested that the floodplain along Sandy Creek was prone to alien upland plant species infestation due to the disconnection of the wetland from Sandy Creek.

We refrain from calling the SWAMP a fully restored wetland since reverting to the original state (Bradshaw, 1996) is an unattainable goal after only a few years (Craft et al., 2003). Instead, the SWAMP is a designed wetland complex that includes riverine, palustrine, and lacustrine wetlands to maximize habitat for biota as well as improve water quality. Like most of wetland restoration practices, the SWAMP project is more properly described as rehabilitation rather than complete restoration (see Vaughn et al., 2010). Nonetheless, the ecological principles, such as diversity-disturbance relationship, that drive the plant community succession are similar, and we thus use the term restoration (Harris and van Diggelen, 2006) throughout this paper.

Half of a century ago, Eugene Odum (1963) stated that the highest biodiversity occurred at the middle of a physical gradient. Later research studies (Grime, 1973; Horn, 1975; Connell, 1978; Huston, 1979) formulated the humpbacked diversity-disturbance relationship into the intermediate disturbance hypothesis (IDH). However, in a cursory examination, Mackey and Currie (2001) found nonunimodal patterns of diversity-disturbance relationship prevalent among the literature. Hughes et al. (2007) suggest a feedback mechanism exists for diversity-disturbance relationship. As such the disturbance can be both a cause and a consequence of local diversity. Based on an extensive meta-analysis, Svensson et al. (2012) found only in a small portion of studies that species richness followed IDH and cautioned that using compound indices as diversity measures required an a priori logical argument.

Invasive species, either as cause or effect, play a role in degraded ecosystems. Rejmánek and Richardson (1996) compiled known processes for ecosystem change and synthesized them into a theory that could help to decipher the invasion mechanism for seed plants, in which $r$-strategy species were considered the most successful invaders. Non-native, invasive species are often thought to act as drivers, which impose their superior competiveness to overwhelm the native community. MacDougall and Turkington (2005) suggest that invasive species are represented more by a passenger model instead of driver model as the underlying avenue to dominance. As a passenger, invasive plants could only hitchhike onto an ecosystem where the native community had been in decline or disrupted. Their findings imply maintaining a diverse ecosystem is the key to combat the opportunist invaders (see Fargione and Tilman, 2005). Bauer (2012) introduced the concept of back-seat driver model, where species possess qualities of both (hitchhiking) passenger and (steering) driver as pathways to dominance, to explain the continuous widespread infestation of such species as
Microstegium vimineum (Japanese stilt grass). Zedler and Kercher (2004) in a review noted that wetlands are especially vulnerable to invasions and that 8 of 33 of the world's most invasive plants are wetland species.

The main purpose of this study is to elucidate how plant communities evolve in a post-restoration floodplain palustrine wetland in the southeastern U.S. We surveyed species composition and tested floristic associations among plant assemblages in conjunction with measured groundwater hydrology, which could help to address the potential hydrologic effect on wetland plant succession for native and invasive plant species. Plant diversity in the context of the intermediate disturbance hypothesis (IDH) was also examined. We also discuss invasive plant issues and strategies in the various types of wetlands found in this southeastern urban setting.

\section{Materials and methods}

\subsection{Location and environment}

The study site $\left(35.991^{\circ} \mathrm{N}, 78.942^{\circ} \mathrm{W}\right)$ is located in Durham, North Carolina (Fig. S1), USA. Dotted with rolling hills, Durham sits in the east-central Piedmont and has a humid subtropical climate with temperatures ranging from -2.3 to $9.6^{\circ} \mathrm{C}$ in January to $21.2-31.4^{\circ} \mathrm{C}$ in July. The expected earliest frost date is October 24 , and the latest frost date is April 13 (Perry, 1998a,b). Annual precipitation is considered adequately abundant at $1220 \mathrm{~mm}$. There is no significant wet/dry season. However, drought periods were not uncommon during our five-year study. Sandy Creek lies in an urban catchment. Most of its headwaters originate from seepage and runoff in residential housing, commercial office, and university campus, where impervious surfaces ( $>20 \%$ ) cover the landscape (Richardson et al., 2011). Upper reaches of Sandy Creek run through the east end of Duke Forest in Durham Division. Sandy Creek intersects Highway NC 751 before entering the SWAMP. During road construction in the 1930s, a concrete box culvert was placed under the intersection to allow drainage to pass through. Based on a topographic map, the passage opening of the culvert is estimated at only $5 \%$ of its original channel width before the highway construction. As a result, the high velocity of storm water vented out of the culvert and deeply scoured the stream channel to a state of severe degradation before restoration. The loose, coarse texture of the sandy streambed for which Sandy Creek is named exacerbated the channel erosion. After four restoration phases during 2004-2007, the SWAMP complex was found to alleviate the stream degradation and the floodplain was reconnected to the stream during overflow events (Richardson et al., 2011).

Supplementary data associated with this article can be found, in the online version, at http://dx.doi.org/ 10.1016/j.ecoleng.2013.05.001.

\subsection{Flora}

A pre-construction survey indicated that the vegetation was dominated by tree species common to the North Carolina Piedmont (Schafale and Weakley, 1990). Liriodendron tulipifera and Liquidambar styraciflua made up more than $70 \%$ of the canopy, whereas L. sinense, Acer negundo, Carya cordiformis and Juglans nigra were the most frequent understory species. The majority of ground cover was occupied by M. vimineum, Lonicera japonica, Hedera helix, and Euonymus fortune, exotic species. Native herbaceous plants were in the minority, including Toxicodendron radicans, Parthenocissus quinquefolia, Smilax rotundifolia, and Amphicarpaea bracteata. The presence of $H$. helix, L. sinense, L. japonica, and M. vimineum was evidence of past disturbances followed by alien species invasion, 


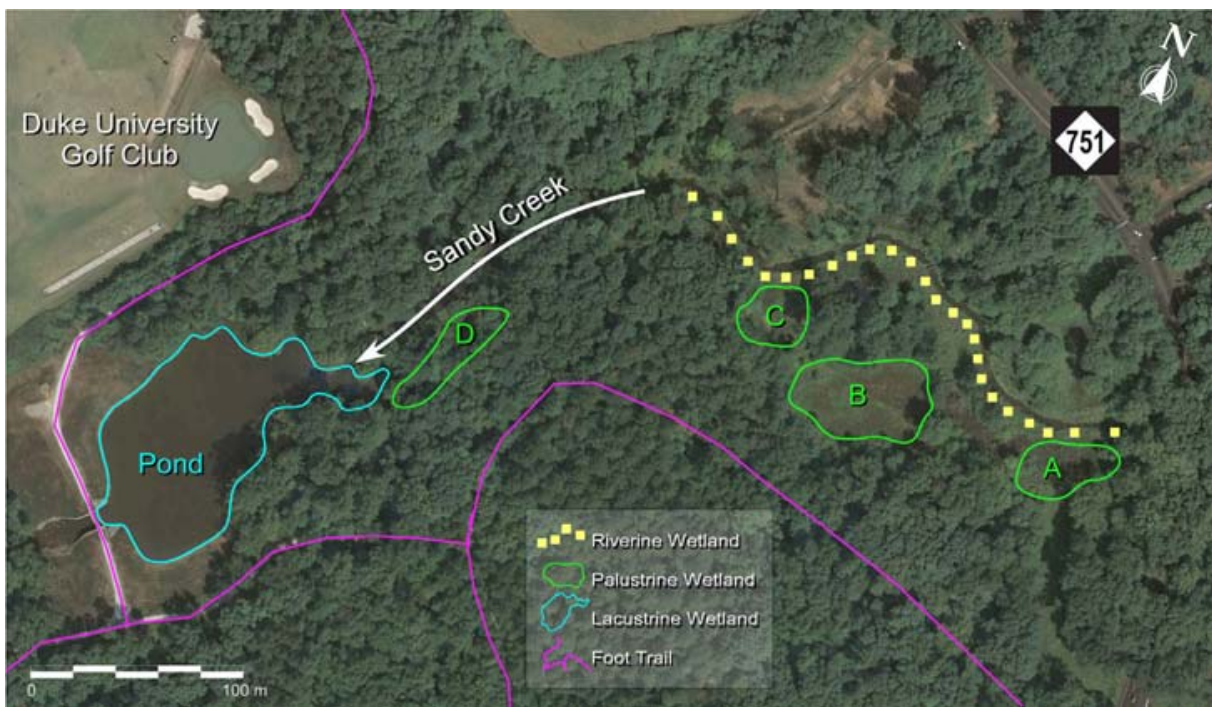

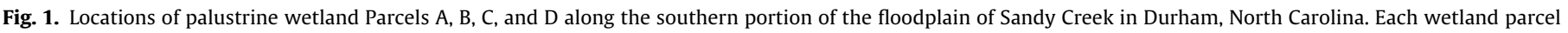
contains paired High Marsh and Low Marsh sites, where survey plots were randomly placed.

partly related to the surrounding urban environment. In addition to the four prevalent alien species, other invasive plants like Celastrus orbiculatus, Dioscorea oppositifolia, Elaeagnus pungens, Elaeagnus umbellata, Glechoma hederacea, Lonicera fragrantissima, were commonly found. The long list of exotic plants suggests the stream degradation was not limited to geomorphologic changes per se as floristic components of the watershed were also adversely affected by invasive species.

\subsection{Soil}

The soil along this section of Sandy Creek is classified as coarseloamy, mixed, nonacid, thermic Aquic Udifluvents. The depths of the water table are within $15-45 \mathrm{~cm}$ from surface. Flooding prior to urbanization was categorized as frequent, and the soil labeled as somewhat poorly drained (Soil Survey Staff, 2012). Although the earth moving activities during stream channel reconfiguration altered the original soil profile, no foreign soils were imported from outside the floodplain. Soil chemical characteristics of the study site were comparable to those of the original undisturbed site (Unghire et al., 2011). After the wetland restoration, however pockets of depressions formed mosaics of micro-environments that gave rise to new habitats and helped diversify plant communities. In particular, restored groundwater patterns after stream restoration exhibited distinct hydrological patterns and gradients among the contrasting terrains.

\subsection{Hydrology}

To monitor groundwater levels, we installed PVC piezometers in various locations around the SWAMP. Within a $1-\mathrm{m}$ radius at each location, a set of piezometers with a $15-\mathrm{cm}$ slot opening centered at 15-, 30-, and 60-cm depths were installed. We used a power auger to excavate a borehole to the desired soil depth. The piezometer was then inserted and adjusted to vertical position and refilled with sand. Bentonite was then used to cap off the top of the borehole to hold fast the piezometer and drain off the rain (see Sprecher, 2007). To take water level readings we devised a graduated rod tipped with two metal electrical prongs attached to an analog multi-volt tester. To take water level readings, we lowered the end of rod with metal prongs into the piezometer casing. When the two prongs contacted water surface, an electrical circuit was established. Depth of the water table was determined when the electrical resistance dial showed a sudden jolt. These readings were calibrated against an automated water well nearby. Biweekly readings of groundwater were recorded. Meteorological information obtained from National Climatic Data Center, NOAA was used to compare rainfall versus groundwater. We used the archived records from Raleigh-Durham Airport $\left(35.8923^{\circ} \mathrm{N}\right.$, $78.7820^{\circ} \mathrm{W}$ ) to approximate our climate information.

\subsection{Vegetation surveys}

Paired palustrine High Marsh and Low Marsh sites were located on four parcels (labeled as A, B, C, and D) of SWAMP wetlands along the southern floodplain of Sandy Creek (Fig. 1). Each wetland parcel consisted of a High Marsh and a Low Marsh, with soil elevations having been contoured $10-15 \mathrm{~cm}$ lower at the Low Marsh areas. Depending on the size of the wetland parcel, six to eight vegetation survey plots $(1 \mathrm{~m} \times 1 \mathrm{~m})$ were randomly spaced in each marsh. A total of 54 plots, 27 High Marsh and 27 Low Marsh, were established. Corners of every permanent plot were marked with a $60-\mathrm{cm}$ long by $2-\mathrm{cm}$ wide PVC pipe. The corner-only markers were to ensure minimal disturbance to plant growth within plot. To delineate plot edges for conducting plant surveys, multiple rubber bands were chained together and surrounded the base of the corner markers. Percent cover of each species was enumerated (MuellerDombois and Ellenberg, 1974) at the end of the growing season around October/November. The surveys were carried out for five years.

\subsection{Data analysis}

We used Radford et al. (1968) for species identification, and the nomenclature of taxa followed the PLANT Database maintained by USDA (2012). Compilation and analyses of raw data were processed using SAS (2010). We utilized PC-ORD software (see McCune et al., 2002) to explore ordination of the plant communities over time through non-metric multidimensional scaling (NMS) procedure. 


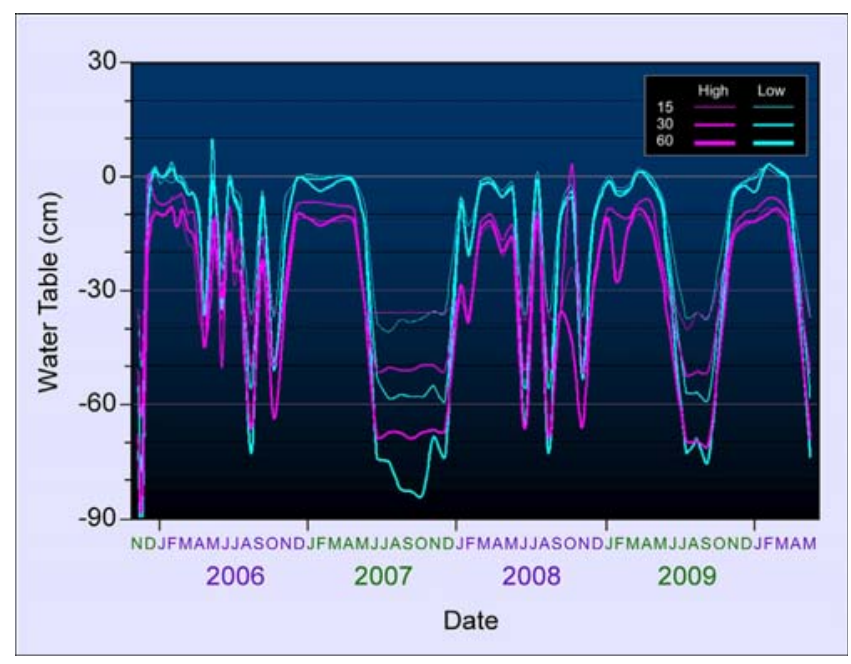

Fig. 2. Water tables measured by three piezometers $(15,30$, and $60 \mathrm{~cm}$ depth $)$ at High Marsh and Low Marsh in wetland Parcel B. The piezometers at three depths of the same marsh are grouped together within a 1-m radius on site. Each breakthrough curve is derived from bi-weekly records of each piezometer.

\section{Results and discussion}

\subsection{Hydrology}

The water tables of piezometers at 15-, 30-, 60-cm depths from wetland Parcel B are representative of groundwater responses of all parcels and fluctuated in sync during each season but with clear water table differences between High Marsh and Low Marsh. The temporal fluctuation of groundwater tables, in general, followed the seasonal change, being wetter near the ground surface in the cool season and drier in the warm season (Fig. 2). When the duration of dry period drawdown is shorter than 8 weeks, the Low Marsh water tables are consistently higher than those in High Marsh. When long-term drought was encountered, the Low Marsh water tables fell below those of High Marsh. The water tables respond to the rainfall patterns (Fig. S2) although the two variables do not correspond linearly to each other. At times when rainfall exceeded percolation, plant uptake, and evaporation, the rising water table extended above ground and waterlogged conditions persisted. Of all the piezometers installed, water tables in Low Marsh were above ground $10-20 \%$ of the time as opposed to $<1 \%$ in the High Marsh sites during the five-years of monitoring. However, the water table could be drawn down below the root zone when extended drought occurred in both the High and Low Marsh sites.

Supplementary data associated with this article can be found, in the online version, at http://dx.doi.org/10.1016/ j.ecoleng.2013.05.001.

The study site was plagued by frequent and prolonged drought during the five-year study. Drought indices complied by Drought Mitigation Center (http://droughtmonitor.unl.edu/) revealed that North Carolina experienced drought spells more than 25\% of time during 2006-2009 period. Between July 24, 2007 and April 15, 2008 , there were 39 weeks of continuous drought without relief (Fig. S3). The drought indices were designed to account for not only rainfall amount, but also timing, evapotranspiration, soil moisture, plant performance, and historical deviation. Only $20 \%$ of the time was North Carolina free of any degree of drought in the 2000-2010 decade (see Fig. S3). The drought-free days dropped to 10\% during our study between 2005 and 2009. Although occasional rainfall lessened drought severity, the multiplicative effects of drought could not be totally erased by sporadic rain events.

Supplementary data associated with this article can be found, in the online version, at http://dx.doi.org/10.1016/ j.ecoleng.2013.05.001.

The adverse hydrological scenarios described above poses a challenge to the interpretation of wetland succession following restoration. However, drought is part of natural processes, and many plant species are reintroduced each year; thus, the chances of establishment are high during a five-year study. A successful wetland community could then replenish itself given a sufficient seedbank and propagules, plant sources which ensures a quick recovery once drought conditions are relieved. Moreover, a successful reestablishment of the wetland community under abnormally dry rainfall periods would further support the successful restoration of the floodplain and stream complex as the main source of ground water at SWAMP during the drought period was from stream bank overflows from occasional large storm events upstream.

\subsection{Vegetation in the palustrine wetland}

A total of 108 plant taxa were identified in our palustrine wetland plots. Among them, 21 obligate (OBL), 7 facultative wet-plus (FACW+), and 17 facultative wet (FACW) wetland species (see USDA, 2012) were found. Juncus effusus is the most widespread and persistent species in the survey. It occurs in every plot of every year's inventory. To a lesser extent, Juncus acuminatus, Boehmeria cylindrica, Carex lurida, and Mimulus ringens also appear widely and frequently. As for non-wetland components, $M$. vimineum facultative plus (FAC+) tops the list of ubiquitous species, followed by Cardamine hirsuta facultative (FAC). Both herbaceous species are non-native to the U.S. Unlike M. vimineum, C. hirsuta is a winter annual that thrives in cold seasons and therefore receives less attention in turns of its invasiveness status. L. tulipifera (FAC), a formerly dominant native tree was also omnipresent in our study site. In addition, three woody vine/trailing subshrubs, $L$. japonica (non-native), Vitis cinerea ssp. baileyana, and Rubus argutus, predominantly occur in the High Marsh. Among the 108 taxa, more than $80 \%$ are native to the U.S. Most of the introduced species occupied drier environments except two wetland species, Murdannia keisak (OBL) and Echinochloa colona (FACW+) that resided in the Low Marshes.

\subsubsection{Species richness}

Collectively, there were more plant species present in the High Marsh than in the Low Marsh (Fig. 3). This pattern is supported by plant community data found in each wetland parcel. However, when species richness is examined across our five-year annual surveys, a more subtle successional trend appears. In the 2005 survey, more than twice as many species were recorded in High Marsh than in Low Marsh. By 2009, more plant species were found in Low Marsh than in High Marsh (Fig. 3). Across all four wetland parcels over five years, we found a decreasing species trend in the High Marsh from 69 to 29 species but an increasing trend in Low Marsh from 24 to 38 species. The proportion of wetland species (OBL, FACW+, FACW combined) increased from 36 to $41 \%$ in the High Marsh and 54 to $66 \%$ in the Low Marsh. The dynamic increases in wetland species over time suggest that the floristic succession is being driven toward wetland communities in both Low Marsh and High Marsh.

Experimental studies (Arthaud et al., 2012) as well as theoretical arguments (Catford et al., 2012) suggest that species richness peaks at the intermediate stage of succession after disturbance. Any engineering activity, including wetland restoration, is an apparent 


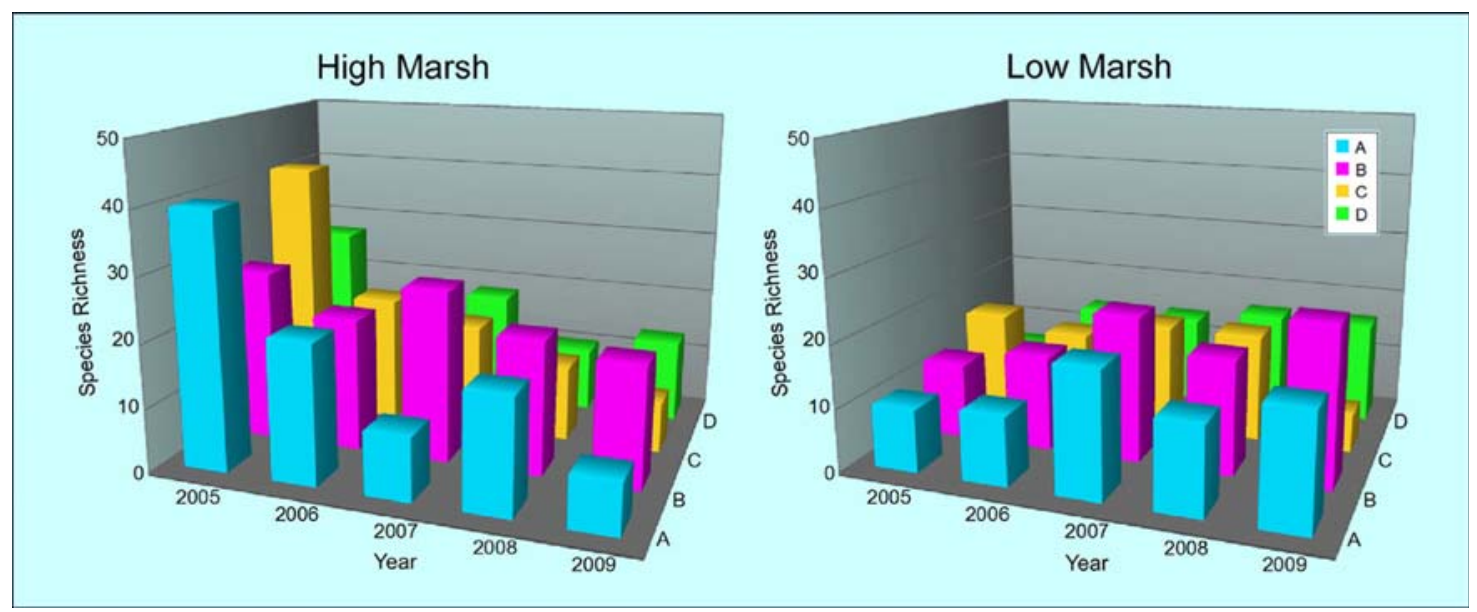

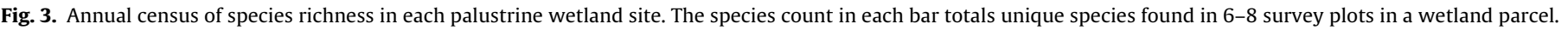
No species common to different survey plots are counted twice. Likewise, any species unique to only one plot is included in the species count.

disturbance to plant community. Our High Marshes experienced an immediate species build up in the first vegetation survey in fall 2005 (Fig. 3) and then a quick decline afterward. On the other hand, the species richness in Low Marshes did not reach a maximum for several years. It is conceivable that the seasonal waterlogged conditions in the Low Marshes precluded the establishment of many species that were flood intolerant. Only a handful of seed plant species are capable of anaerobic germination (Kennedy et al., 1980, 1992). Recruitment for the Low Marsh from a smaller pool of wetland species would also be slower compared to that for the High Marsh, which had species introduction from a much larger adjacent pool of non-wetland species.

Citing the parallel dynamics hypothesis, McLane et al. (2012) observed bottomland hardwood forest restoration from a chronosequence spanning almost a century. They concluded that invasive herbaceous species and native species exhibited the same temporal patterns in terms of species richness. Following a Weibull distribution, both the invasive and the native species occur in numerous taxa in the early succession and then consistently decline over time, a trend we found in our study.

\subsubsection{Invasive species}

$M$. vimineum, one of the most aggressive invasive species in the southeastern U.S. grows on non-native lands across a variety of habitats and outperforms the local populations in its native range (Flory et al., 2011). Their findings highlight how native ecosystems in the U.S. could be susceptible to M. vimineum invasion. However, the scope of $M$. vimineum invasiveness was limited to local spread only according to some researchers (Gibson et al., 2002; Cheplick, 2010; Rauschert et al., 2010). DeMeester and Richter (2010) made a successful effort to regain native species richness in the piedmont of North Carolina (from 4 to 15 species) by manually removing $M$. vimineum from a forested wetland but $M$. vimineum quickly reinvaded the plots after weeding was stopped and species richness dropped to 8 species. Moreover, the labor-intensive operation could not be applied to large-scale infestations. Studying $M$. vimineum performance at various stages of life history, Warren et al. (2011) suggested that significant niche limitations (nutrients, flooding etc.) could be utilized as a management tool aiding eradication.

Our most abundant herbaceous invasive species in the Duke Forest floodplain in the pre-construction ground cover, $M$. vimineum, continued to infest the area after the creation of SWAMP. However, little M. vimineum was found in the first survey in 2005, the fall season after restoration (Fig. 4). The High Marsh in the wetland Parcel D quickly reached $>50 \%$ areal cover of M. vimineum by 2006 . The High Marshes in all wetland parcels contained $>50 \%$ cover of $M$. vimineum at the fifth year after restoration. The Low Marshes in Parcels C and D had results similar to those in the High Marsh, with M. vimineum increasing. Conversely, the Low Marsh in Parcels $A$ and $B$ remained unaffected by $M$. vimineum presence throughout the entire survey period. These were our wettest wetland parcels at SWAMP and often had standing water for extended periods (Fig. 2).

In a study of physiological responses, Touchette and Romanello (2010) suggested that M. vimineum could maintain a normal growth under flood conditions. We observed no $M$. vimineum presence in the waterlogged Low Marsh plots when germination commenced in the wet, but not waterlogged High Marsh plots. Depending on the persistence of the inundation in the Low Marsh areas, M. vimineum may return especially during the drier summer periods. Although often present by the end of growing season in some plots, the slower start by M. vimineum in wetter plots could not reach maturity to set seeds before a killing frost, a condition also found by Barden (1987). For an annual grass species, without successful

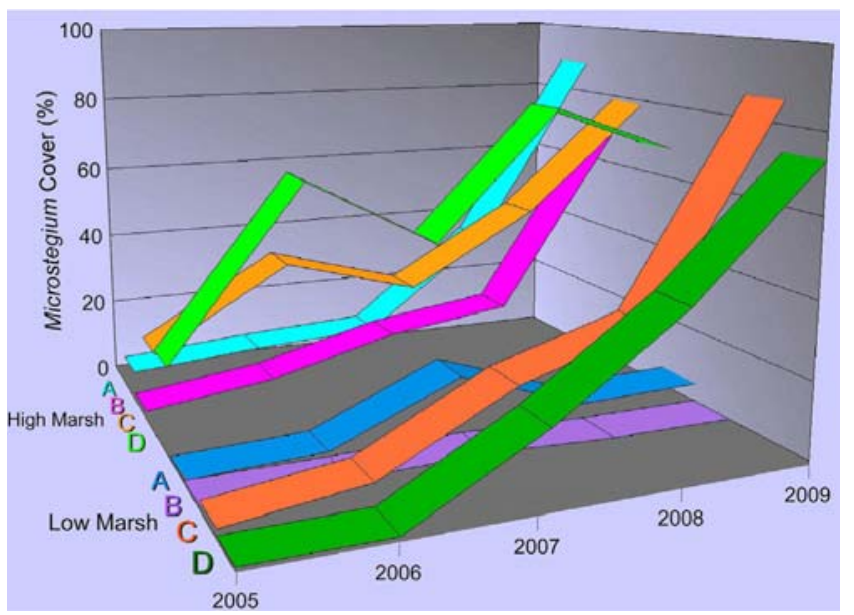

Fig. 4. Areal cover of Microstegium vimineum in each palustrine wetland site over five years after riparian restoration in 2005. The proportional cover is a cumulative measure of six to eight randomly placed permanent plots within each wetland parcel. 
seed production in situ, disruption of the cohort establishment is inevitable.

Avoiding chemical approaches, Flory and Lewis (2009) found mowing and autumn fire significantly reduce $M$. vimineum cover by $70-79 \%$ and biomass by $90-95 \%$. However, given the lasting seed viability up to five years (Barden, 1987), a new M. vimineum population could be revived from a few viable seeds in the remnant seed bank. Despite the tenacity of $M$. vimineum, our data suggests prolonged inundation prevent germination and appears to be a plausible strategy to curtail its proliferation in restored floodplains. This is easily accomplished by providing areas near the stream bank and in the floodplain with lower soil surfaces and elevations conducive to stream overbank flooding.

Before wetland restoration, the introduced species $L$. sinense was a major understory woody shrub that could effectively reduce native biodiversity (Greene and Blossey, 2012). L. sinense does not produce seeds in abundance until it reaches large stature in sunny conditions (Morris et al., 2002). Expansion of this species was of concern due to the removal of upland canopy trees in large portions of the restored floodplain. The invasive $L$. sinense was not present in any post-construction survey plots, a beneficial outcome of the hydrologic connection of the floodplain with the stream in the SWAMP restoration. In a riparian forest, Hanula et al. (2009) found that the richness of native herbaceous species successfully recovered after $L$. sinense removal, a condition we also observed at SWAMP. With continued removal of $L$. sinense seedlings, we expect this exotic shrub to be phased out of the palustrine wetlands in SWAMP or at least diminished to a manageable population.

\subsubsection{Ordination}

To test for the long-term influence of hydrologic restoration and invasive species on plant succession we completed a Non-metric Multidimensional Scaling (NMS) ordination. Ordination results showing a scattergram of plant species and marsh parcel trajectories (A, B, C, and D) over the five-year period of sampling are presented in Fig. 5. The length of the trajectory lines indicates the amplitude of vegetation change from year one to year five, with the longer lines reflecting the most successional change. Italic letters (see Appendix 1 for species codes) denote 20 wetland species with OBL or FACW status; letters within rectangular frames are non-native species. The ordination was performed using log-transformed relative abundance (areal cover). Sørensen distance matrix was employed for the 40 groups ( 4 wetland parcels $\times 2$ hydrologically distinct marshes $\times 5$ years of annual survey) by 80 species (after rare species were excluded) analysis. Two-dimensional results were considered with real data and randomized data of 999 runs each with a Monte Carlo test result $P=0.001$. Best results were obtained with iteration $=499$, final stress $=16.96$, instability $=0.046$. Simultaneous varimax rotation was applied to both axes. The coefficient of determination between distances of the

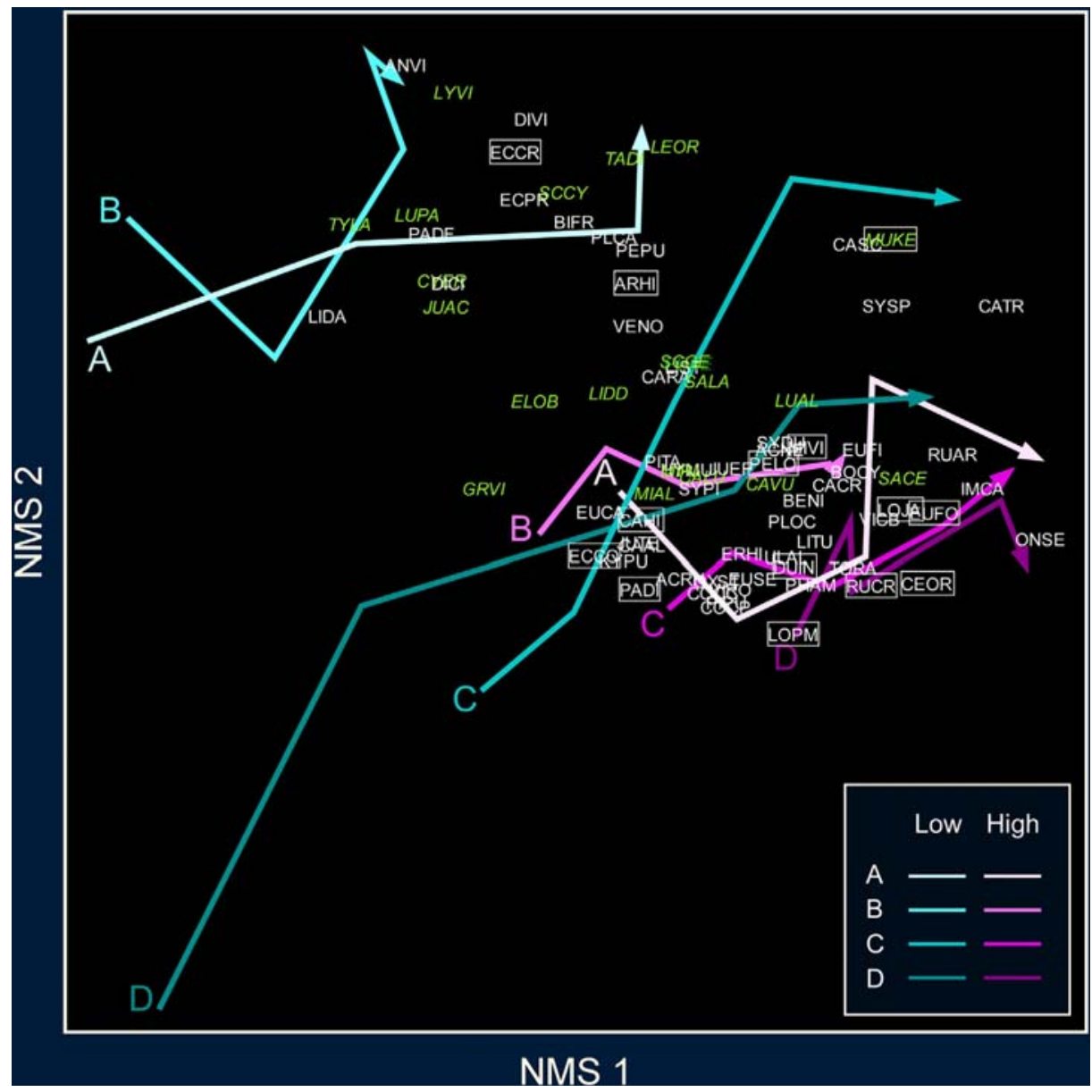

Fig. 5. Ordination result of Non-metric Multidimensional Scaling (NMS) showing scattergram of plant species and marsh (High, Low) $\times$ wetland parcel (A, B, C, and D)

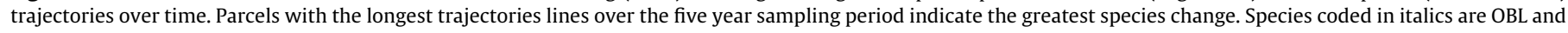
FACW wetland plants. Rectangular framed codes are non-native species. Scientific names of species codes are listed in Appendix 1. 
ordination axis and distances of the Sørensen similarity matrix were $R^{2}=0.620$ for NMS axis 1 , and $R^{2}=0.178$ for NMS axis 2 . Overall nearly $80 \%(0.620+0.178)$ of the original variation was explained by the first two NMS axes. Most of the OBL wetland species clustered in the upper left quadrant, while non-native, upland and FAC wetland species concentrated in the lower right quadrant.

Supplementary data associated with this article can be found, in the online version, at http://dx.doi.org/10.1016/ j.ecoleng.2013.05.001.

The NMS axis 1 was most closely related to $M$. vimineum $(r=0.94)$. Other species such as $L$. japonica, an invasive species (0.68), J. acuminatus (-0.65), B. cylindrica (0.55), Typha latifolia $(-0.55)$, and $R$. argutus (0.54) were also important. Thus, the invasive $M$. vimineum is not the sole determinant of successional dynamics for plant communities. In the NMS ordination plot (Fig. 5), the most inundated Low Marshes (flooded 10-20\% of time) in Parcels A and B, which spanned within the upper left quadrant of the scattergram, clearly differ from the other succession trajectories. In sharp contrast, M. vimineum distribution prevailed among drier habitats shown on the right side of the NMS axis 1 (Fig. 5). The trajectories for Low Marsh in wetland Parcels C and D were the longest, which indicates a more drastic change of floristic composition over time at these habitats. The infrequent incidences of inundation $(<7.5 \%)$ may be responsible for the loss of OBL species from these wetland parcels.

\section{Conclusions}

Our study in the SWAMP complex focused on vegetation succession dynamics in palustrine floodplain communities of the piedmont of North Carolina for five years after restoration and engineering activities. The most natural wetland successional trajectories occurred in the wettest sites after restoration. Species richness increased by $58 \%$ in Low Marshes, but decreased by $58 \%$ in High Marshes over the five-year restoration.

One of the critical issues dealing with urban riparian ecosystems is invasive species. The initial clearing of $L$. sinense from our restoration area appeared to be effective. No privet was found in our sampling plots after five years. Conversely, the earth moving operation during site preparation actually promoted $M$. vimineum dispersal. Our results showed that most of the marshlands understory was overwhelmed by invasive $M$. vimineum in a few seasons. Despite the pervasiveness of $M$. vimineum in our restoration site, there were hydrologic treatments that curtailed its expansion. The wettest Low Marshes in the two upstream wetland parcels were only slightly affected by $M$. vimineum. We postulated that the frequent inundation of the Low Marshes prevented the establishment of $M$. vimineum. During the exceptional drought in 2007, there was a brief presence of $M$. vimineum in the upstream Low Marsh. However, it did not persist once the rain events returned to normal in 2008.

Given the positive successional wetland patterns related to hydrologic conditions in Low Marshes, we recommend (1) creation of lower riparian terraces to maintain waterlogged conditions to discourage Microstegium colonization in the floodplain, (2) use of native perennials like Juncus spp. and Carex spp. as ground cover to compete against opportunist species invasions, and (3) active removal of non-native woody species, such as $L$. sinense, during restoration followed by the planting of native $A$. gigantea along stream banks to stabilize the banks and prevent the invasion of the exotic Chinese privet (Osland et al., 2009).

\section{Acknowledgments}

We thank Drs. J. DeMeester, A. McHugh, J. Morse, M. Osland, J. Pahl, and A. Sutton-Grier, for their assistance in the preconstruction vegetation survey and installing permanent plots and piezometers. Suggestions by Dr. H. Wang to condense our presentation materials are very helpful. A special thanks to Dr. R. Neighbarger, whose timeless efforts made this manuscript readable. Financial support was largely provided by EPA STAR grant (833837010), EPA, 319(h) Nonpoint Source Program from the N.C. Department of Environment and Natural Resources, and by a grant from N.C. Clean Water Management Trust Fund, and funds from the Duke University Wetland Center Endowment. Duke Forest manager J. Edeburn and Durham County Soil and Water Conservation District director E. Culberson have been major supporters in the SWAMP creation endeavor.

\section{References}

Arthaud, F., Vallod, D., Robin, J., Wezel, A., Bornette, G., 2012. Shortterm succession of aquatic plant species richness along ecosystem productivity and dispersal gradients in shallow lakes. J. Veg. Sci., http://dx.doi.org/10.1111/j.1654-1103.2012.01436.x.

Barden, L.S., 1987. Invasion of Microstegium vimineum (Poaceae), an exotic, annual, shade-tolerant, C4 grass, into a North Carolina floodplain. Am. Midl. Nat. 118 (1), 40-45

Bauer, J.T., 2012. Invasive species: "back-seat drivers" of ecosystem change? Biol. Invasions 14 (7), 1295-1304

Bradshaw, A.D., 1996. Underlying principles of restoration. Can. J. Fish. Aquat. Sci. 53 (Suppl. 1), 3-9.

Catford, J.A., Daehler, C.C., Murphy, H.T., Sheppard, A.W., Hardesty, B.D., Westcott D.A., Rejmánek, M., Bellingham, P.J., Pergl, J., Horvitz, C.C., Hulme, P.E., 2012. The intermediate disturbance hypothesis and plant invasions: implications for species richness and management. Perspect. Plant Ecol. 14 (3), 231-241.

Cheplick, G.P., 2010. Limits to local spatial spread in a highly invasive annual grass (Microstegium vimineum). Biol. Invasions 12 (6), 1759-1771.

Connell, J.H., 1978. Diversity in tropical rain forests and coral reefs. Science 199 (4335), 1302-1310.

Costanza, R., d'Arge, R., de Groot, R., Farber, S., Grasso, M., Hannon, B., Naeem, S., Limburg, K., Paruelo, J., O’Neill, R.V., Raskin, R., Sutton, P., van den Belt, M., 1997. The value of the world's ecosystem services and natural capital. Nature 387 (6630), 253-260

Craft, C., Megonigal, P., Broome, S., Stevenson, J., Freese, R., Cornell, J., Zheng, L., Sacco, J., 2003. The pace of ecosystem development of constructed Spartina alterniflor marshes. Ecol. Appl. 13 (5), 1417-1432.

DeMeester, J.E., Richter, D.D., 2010. Restoring restoration: removal of the invasive plant Microstegium vimineum from a North Carolina wetland. Biol. Invasions 12 (4), 781-793.

Fargione, J.E., Tilman, D., 2005. Diversity decreases invasion via both sampling and complementarity effects. Ecol. Lett. 8 (6), 604-611.

Flory, S.L., Lewis, J., 2009. Nonchemical methods for managing Japanese stiltgrass (Microstegium vimineum). Invasive Plant Sci. Manage. 2 (4), 301-308.

Flory, S.L., Long, F., Clay, K., 2011. Invasive Microstegium populations consistently outperform native range populations across diverse environments. Ecology 92 (12), 2248-2257

Gibson, D.J., Spyreas, G., Benedict, J., 2002. Life history of Microstegium vimineum (Poaceae), an invasive grass in southern Illinois. J. Torr. Bot. Soc. 129 (3) 207-219.

Greene, B.T., Blossey, B., 2012. Lost in the weeds: Ligustrum sinense reduces native plant. Biol. Invasions 14 (1), 139-150.

Grime, J.P., 1973. Competitive exclusion in herbaceous vegetation. Nature 242 (5396), 344-347

Hanula, J.L., Horn, S., Taylor, J.W., 2009. Chinese privet (Ligustrum sinense) removal and its effect on native plant communities of riparian forests. Invasive Plant Sci. Manage. 2 (4), 292-300

Harris, J.A., van Diggelen, R., 2006. Ecological restoration as a project for global society. In: van Andel, J., Arons, J. (Eds.), Restoration Ecology: The New Frontier. Blackwell Science, Oxford, UK, pp. 3-15.

Horn, H.S., 1975. Markovian properties of forest succession. In: Cody, M.L., Diamond, J.M. (Eds.), Ecology and Evolution of Communities. Belknap Press, MA, USA, pp. 196-211.

Hughes, A.R., Byrnes, J.E., Kimbroand, D.L., Stachowicz, J.J., 2007. Reciprocal relationships and potential feedbacks between biodiversity and disturbance. Ecol. Lett. 10 (9), 849-864.

Huston, M., 1979. A general hypothesis of species diversity. Am. Nat. 113 (1), 81-101.

Kennedy, R.A., Barrett, S.C.H., VanderZee, D., Rumpho, M.E., 1980. Germination and seedling growth under anaerobic conditions in Echinochloa crus-galli (barnyard grass). Plant Cell Environ. 3 (4), 243-248. 
Kennedy, R.A., Rumpho, M.E., Fox, T.C., 1992. Anaerobic metabolism in plants. Plant Physiol. 100 (1), 1-6.

MacDougall, A.S., Turkington, R., 2005. Are invasive species the drivers or passengers of change in degraded ecosystems? Ecology 86 (1), 42-55.

Mackey, R.L., Currie, D.J., 2001. The diversity-disturbance relationship: is it generally strong and peaked? Ecology 82 (12), 3479-3492.

McCune, B.J., Grace, B., Urban, D.L., 2002. Analysis of Ecological Communities. MjM Software Design, Gleneden Beach, OR

McLane, C.R., Battaglia, L.L., Gibson, D.J., Groninger, J.W., 2012. Succession of exotic and native species assemblages within restored floodplain forest: a test of the parallel dynamics hypothesis. Restor. Ecol. 20 (2), 202-210.

Morris, L., Walck, J., Hidayati, S., 2002. Growth and reproduction of the invasive Ligustrum sinense and native Forestiera ligustrina (Oleaceae): implications for the invasion and persistence of a nonnative shrub. Int. J. Plant Sci. 163 (6), 1001-1010.

Mueller-Dombois, D., Ellenberg, H., 1974. Aims and Methods of Vegetation Ecology. John Wiley \& Sons, New York.

Odum, E.P., 1963. Ecology. Holt, Rinehart \& Winston, New York.

Osland, M.J., Pahl, J.W., Richardson, C.J., 2009. Native bamboo [Arundinaria gigantea (Walter) Muhl., Poaceae] establishment and growth after the removal of an invasive non-native shrub (Ligustrum sinense Lour., Oleaceae): implications for restoration. Castanea 74 (3), 247-258.

Perry, K.B., 1998a. Average Last Spring Frost Dates for Selected North Carolina Locations. North Carolina Department of Horticultural Science Extension, Horticulture Information Leaflet HIL-707, http://www.ces.ncsu.edu/ depts/hort/hil/hil-707.html (accessed 16.06.12).

Perry, K.B., 1998b. Average First Fall Frost Dates for Selected North Carolina Locations. North Carolina Department of Horticultural Science Extension, Horticulture Information Leaflet HIL-708, http://www.ces.ncsu.edu/ depts/hort/hil/hil-708.html (accessed 16.06.12).

Radford, A.E., Ahles, H.E., Bell, R.C., 1968. Manual of the Vascular Flora of the Carolinas. The University of North Carolina Press, Chapel Hill, NC.

Rauschert, E.S.J., Mortensen, D.A., Bjørnstad, O.N., Nord, A.N., Peskin, N., 2010. Slow spread of the aggressive invader, Microstegium vimineum (Japanese stiltgrass). Biol. Invasions 12 (3), 563-5793.

Rejmánek, M., Richardson, D.M., 1996. What attributes make some plant species more invasive? Ecology 77 (6), 1655-1661.
Richardson, C.J., 1994. Ecological functions and human values in wetlands: a framework for assessing impact. Wetlands $14(1), 1-9$

Richardson, C.J., Flanagan, N., Ho, M., Pahl, J.W., 2011. Integrated stream and wetland restoration: a watershed approach to improved water quality and ecosystem services on the landscape. Ecol. Eng. 37 (1), 25-39.

SAS Institute Inc., 2010. SAS OnlineDoc 9.1.3. SAS Institute Inc., Cary, NC.

Schafale, M.P., Weakley, A.S., 1990. Classification of the Natural Communities of North Carolina, Third Approximation. North Carolina Natural Heritage Program, Department of Environment and Natural Resources, Raleigh, NC.

Soil Survey Staff, Natural Resources Conservation Service, United States Department of Agriculture, 2012. Web Soil Survey, Available at: http://websoilsurvey.nrcs.usda.gov/ (accessed 16.06.12).

Sprecher, S., 2007. Installing Monitoring Wells and Piezometers, ftp:// ftp-fc.sc.egov.usda.gov/NSSC/NCSS/Conferences/national/2007/sprecher.pdf

Sutton-Grier, A.E., Wright, J., McGill, B., Richardson, C., 2011. Environmental conditions influence the plant functional diversity effect on denitrification potential. PLoS ONE 6 (2), e16584, http://dx.doi.org/10.1371/journal.pone.0016584.

Svensson, J.R., Lindegarth, M., Johnson, P.R., Pavia, H., 2012. Disturbances-diversity models: what do they really predict and how are they tested? Proc. R. Soc. B 279 1736), 2163-2170.

Touchette, B.W., Romanello, G.A., 2010. Growth and water relations in a central North Carolina population of Microstegium vimineum (Trin.) A. Camus. Biol. Invasions 12 (4), 893-903.

Unghire, J.M., Sutton-Grier, A.E., Flanagan, N.E., Richardson, C.J., 2011. Spatial impacts and wetland restoration on riparian soil properties in the North Carolina Piedmont. Restor. Ecol. 19 (6), 738-746.

USDA, NRCS, 2012. The PLANTS Database, http://plants.usda.gov (accessed 16.06.12).

Vaughn, K.J., Porensky, L.M., Wilkerson, M.L., Balachowski, J., Peffer, E., Riginos, C., Young, T.P., 2010. Restoration ecology. Nat. Educ. Knowl. 1 (8), 66.

Warren, I.I., Wright, R.J., Bradford, J.P.M.A., 2011. The putative niche requirements and landscape dynamics of Microstegium vimineum: an invasive Asian grass. Biol. Invasions 13 (2), 471-483.

Zedler, J.B., Kercher, S., 2004. Causes and consequences of invasive plants in wetlands: opportunities, opportunist and outcomes. Crit. Rev. Plant Sci. 23 (5), 431-452. 